\title{
LONG TERM BEHAVIOUR OF AN ASPHALT PAVEMENT STRUCTURE CONSTRUCTED ON A GEOGRID-REINFORCED SUBGRADE OVER SOFT SOILS
}

\author{
AURIMAS ŠIUKŠČIUS ${ }^{*}$, VIKTORAS VOROBJOVAS ${ }^{2}$, \\ AUDRIUS VAITKUS' ${ }^{2}$, ŠARŪNAS MIKALIŪNAS ${ }^{3}$, \\ ATIS ZARIN̦Š ${ }^{4}$ \\ ${ }^{1}$ Dept of Roads, Vilnius Gediminas Technical University, Vilnius, Lithuania \\ ${ }^{2}$ Road Research Institute, Vilnius Gediminas Technical University, \\ Vilnius, Lithuania \\ ${ }^{3}$ Dept of Automobile Engineering, Vilnius Gediminas Technical University, \\ Vilnius, Lithuania \\ ${ }^{4}$ Dept of Roads and Bridges, Riga Technical University, Riga, Latvia
}

Received 25 April 2019; accepted 29 May 2019

\begin{abstract}
Many roads with asphalt pavement are being reconstructed every year, as their quality becomes insufficient by the requirements. As it is wellknown, old roads were built not in the very best quality, so doing reconstruction projects in the most cases there were required to deal with soft soils that are under the existing road structure. Geogrid reinforcement was widely used
\end{abstract}

* Corresponding author. E-mail: aurimas.siukscius@vgtu.lt

Aurimas ŠIUKŠČIUS (ORCID 0000-0001-8994-0952)

Viktoras VOROBJOVAS (ORCID 0000-0001-9420-0668)

Audrius VAITKUS (ORCID 0000-0001-5103-9747)

Šarūnas MIKALIŪNAS (ORCID 0000-0001-6143-7650)

Atis ZARIN̦Š (ORCID 0000-0003-1731-2206)

Copyright (C) 2019 The Author(s). Published by RTU Press

This is an Open Access article distributed under the terms of the Creative Commons Attribution License (http://creativecommons.org/licenses/by/4.0/), which permits unrestricted use,

distribution, and reproduction in any medium, provided the original author and source are credited. 
to solve issues of soft soil in Lithuania. There are projects where geogrid reinforcement is used to control road pavement roughness when there are layers of peat or silt under road structure instead of using concrete piles or geosynthetic-encased soil columns. This type of geogrid reinforcement application is unexplained in any normative-technical document but widely used in Lithuania. This application was usually made constructively without any calculations, choosing the reinforced solution by reducing the geogrid tensile strength or layer quantity compared to reinforced load transfer platform over piles. This paper evaluates the long-term influence of geogridreinforced subgrade on the roughness of asphalt surfacing and bearing capacity of the road structure when the soft peaty soils stratify in the deeper layers of the subgrade. There were compared the reinforced sections to adjacent sections to see the effect and fortunately a large number of adjacent sections were also strengthened, mostly by lime stabilisation. Therefore, this comparison allows making more insights on the long-term performance of the strengthened subgrade and influence on the road quality. This research gives recommendations on how the geogrids has to be selected to be used in this kind of application.

Keywords: bearing capacity, geogrids, geosynthetics, pavement roughness, soft soil, soil reinforcement, subgrade.

\section{Introduction}

Due to the deterioration of the Lithuanian road conditions, the asphalt pavement roads are being reconstructed every year. To prepare a reconstruction project of the road with the old asphalt surfacing, the designer has to evaluate geotechnical investigations. It is essential to understand the geotechnical conditions of the subgrade and this is quite hard when dealing with atypical situations. It is usual for a designer to find peat or silt layers under the subgrade of the existing road, especially when the road is crossing areas with lakes or swamps nearby. However, it is often quite hard to evaluate how to solve a soft soil problem in the most efficient way.

By the Lithuanian normative-technical documentation IT ŽS17 Automobiliu keliu žemės darbu atlikimo ir žemės sankasos įrengimo taisyklés designer has two options to solve cases with peat and silt in the subgrade, either to dig it out and replace it with better quality soil, e.g. sand and gravel, or to install piled embankment. This problem of the soft peaty soil in the existing subgrade is actual not only in Lithuania but also in other countries (Poland, Latvia, Ukraine and others). Lithuanian road reconstruction projects had to deal with 0.4-1.4 m thickness of well-decomposed peat and (in some places) additional $0.7-1.5 \mathrm{~m}$ thickness of the silt layer that starts in 2.0-3.0 m depth from the top of the existing road structure. To install piles
Aurimas Šiukščius, Viktoras Vorobjovas, Audrius Vaitkus, Šarūnas Mikaliūnas, Atis Zarinš

Long Term Behaviour of an Asphalt

Pavement Structure

Constructed on a Geogrid-

Reinforced Subgrade Over Soft Soils 
for such conditions is a costly solution, knowing that peat or silt has some level of consolidation. This condition is critical when there is a need to increase the quality of the roads when having the same budget for road maintenance (Vaitkus, Čygas, Motiejūnas, Pakalnis, \& Miškinis, 2016). This problem remains significant. For this reason, after the geosynthetic materials were being started to be used in Lithuania, many road reconstruction projects with asphalt pavement have been implemented over ten years. Those projects used geogrid reinforcement instead of peat excavation and replacement or pile system installation (Wallbaum, Busser, Itten, \& Frischknecht, 2014), various strength geogrids were used directly under the road structure or a bit lower, making the replacement with geogrid-reinforced frostblanket course up to $0.6 \mathrm{~m}$ of the existing soil.

The expectations of using geogrid reinforcement for subgrade strengthening was that the reinforced soil under the road structure has to prevent road pavement from cracks, ruts, potholes or bumps that could be caused by the existing partially consolidated layers of soft peaty soil. This type of asphalt pavement structure strengthening is still being used. However, it is not described in the technical guide for geosynthetics used in the road soil work applications MN GEOSINT ŽD 13 Geosintetikos naudojimo žemès darbams keliuose metodiniai nurodymai (issued in Lithuania in 2013 by Lithuanian Road Administration under the Ministry of Transport and Communications) and neither normative documents of other countries (Vaitkus, Šiukščius, \& Ramūnas, 2014) or in other design codes (Meyer \& Elias, 1999).

Cuelho \& Perkins (2016) performed large-scale field trials to identify the most critical geogrid properties for a sufficient stabilisation and (or) reinforcement function. These field trials concluded that the geogrids, which performed the best were rigid, had stiff junctions and enough tensile strength. However, this field trial is performed using unpaved road constructions and soft clay subgrade, as it is for most of the field trials.

Another type of test, using two layers of stiff geogrid, was performed to investigate the strain level in the geogrid reinforcement and the lateral movement of the entire structure due to post-construction settlement using a paved road structure (Vollmert, Emerslen, \& Retzlaff, 2014). It showed that in the working phase, the plastic strains are tiny compared to the elastic strains even in very rigid structures. The study also showed that still a certain amount of plastic deformations are found even in very rigid structures. The tensile stresses must be absorbed to limit the amount of plastic deformation, even if they are developed at 
tiny strains. Moreover, that research had a geological condition, which had weak peaty clay or fine to coarse sand with some peat layers. However, it did not have more of the peat layers under the tested structure, and it cannot be a direct example of the problem described above.

Valero, Sprague, \& Wrigley (2014) did a full-scale trafficking test of geogrid-reinforced subgrade using typical road structure with asphalt pavement. They indicated that all types of geogrid improve pavement-rutting resistance even under severe conditions. However, the subgrade was without any peat layers; it had moisture-sensitive silty sand.

For this reason, large-scale test sections were used to determine whether the geogrid-reinforced subgrade is suitable, looking from the long-term perspective, to compensate for the compressible subgrade conditions. This research covered the International Roughness Index (IRI, m/km) measurements and bearing capacity measurements using Falling Weight Deflectometer (FWD). The aim was to analyse if asphalt pavement with geogrid reinforcement over partially consolidated peat has a trend to perform well after seven years of construction and how geogrid reinforcement influence the IRI (Šiukščius, Vorobjovas, \& Vaitkus, 2017). It is also compared to the adjacent sections to identify how it performs in a general view of the road structure.

\section{Tested road sections and designed solutions}

To be able to get more reliable results, two different categories of roads were selected for the examination when estimating the geogrid influence on the pavement roughness (Šiukščius, Vorobjovas, \& Vaitkus, 2018). The first road was the main road A6 Kaunas-Zarasai-Daugpilis (tested sections $66.20-68.76 \mathrm{~km}$ and $137.35-142.00 \mathrm{~km}$ ). The second road was the national road No. 131 Alytus-Simnas-Kalvarija (tested sections $44.80-50.80 \mathrm{~km}$ and $52.45-57.12 \mathrm{~km}$ ). Reconstruction of these roads was more than eight years ago. It was found that 11 sections have the situations as mentioned above, where there are filled soils over the peat or silt layers and where the geogrid reinforcement was used under the road structure.

The worst geological situation is in the main road A6 section 67.26-67.45 km. A $0.9-1.4 \mathrm{~m}$ thickness of the peat layer, which is compressed until $30 \%$ and it starts in 2.3-3.4 m depth. Under the peat layer, in a $2.3-4.8 \mathrm{~m}$ depth, there is $0.7-1.5 \mathrm{~m}$ thickness of silt layer. Therefore, in total, there are up to $2.9 \mathrm{~m}$ of very soft peaty silty soil
Aurimas Šiukščius, Viktoras Vorobjovas, Audrius Vaitkus, Šarūnas Mikaliūnas, Atis Zarinš

Long Term Behaviour of an Asphalt

Pavement Structure

Constructed on a GeogridReinforced Subgrade Over Soft Soils 
that is $1.98 \mathrm{~m}$ under the road structure. The majority of the sections has the geological situation where there are well decomposed (medium decomposed in the national road No. 131 (46.45-46.72 km)) 0.4-1.3 m thickness of soft peaty soil, and it starts in 2.0-3.1 m depth. Usually, the groundwater level is fully covering the soft peaty and silty soils, and, in some cases, is up to $0.5 \mathrm{~m}$ higher.

The road structures were devided into four types comparing the designed solutions based on the IT APM 10 Automobiliu keliu asfalto dangu priežiūrai skirtu medžiagu ir medžiagu mišiniu panaudojimo ir ju sluoksniu ìrengimo taisykles and KTR 1.01:2008 Automobiliu keliai. The first and the weakest one is the road structure No. 1 for the main road A6 $(67.26-67.45 \mathrm{~km})$. A $30 / 30 \mathrm{kN} / \mathrm{m}$ tensile strength polypropylene (PP) geogrid and a GRK3 class non-woven geotextile (mass per unit area no less than $150 \mathrm{~g} / \mathrm{m}^{2}$; resistance to static puncture no less than $1.5 \mathrm{kN}$ by MN GEOSINT ŽD 13) were installed directly under the crushed dolomite mix 0/45 layer (Figure 1). The second road structure No. 2 is for the national road No. 131 (53.91-54.09 km, 55.00-55.09 km, and 56.74-56.94 km). A $60 / 60 \mathrm{kN} / \mathrm{m}$ tensile strength PP geogrid (crosswise) and a GRK3 were installed with a $0.3 \mathrm{~m}$ of soil replacement under the road structure (Figure 2). The third road structure No. 3 is for the national road No. 131 (45.965-46.140 km, 46.45-46.72 km, $46.865-46.950 \mathrm{~km}, 47.320-47.425 \mathrm{~km}$, and 49.220-49.295 km). A $60 / 60 \mathrm{kN} / \mathrm{m}$ tensile strength PP geogrid (crosswise in two layers at every $0.3 \mathrm{~m}$ ) and a GRK3 were installed with a total of $0.6 \mathrm{~m}$ of soil replacement under the road structure (Figure 3). The fourth road structure No. 4 is for the main road A6 (41.047-141.123 km). A $400 / 40 \mathrm{kN} / \mathrm{m}$ tensile strength polyester (PET) geogrid in crosswise direction, a 200/40 kN/m tensile strength PET geogrid along the road, and a GRK3 were installed with a $0.3 \mathrm{~m}$ of soil replacement under the road structure (Figure 4).

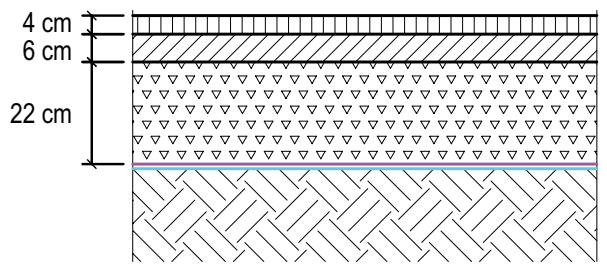

Asphalt concrete AC $11 \mathrm{VS}$

\begin{tabular}{l}
\hline Asphalt concrete AC 16 AS \\
\hline Crushed dolomite mix. 0/45 \\
\hline Geogrid from PP $30 / 30 \mathrm{kN} / \mathrm{m}$ \\
\hline Nonwoven geotextile GRK3
\end{tabular}

Existing road structure

Note: main road A6 (67.26-67.45 km); measurements in cm.

Figure 1. Road structure No. 1 


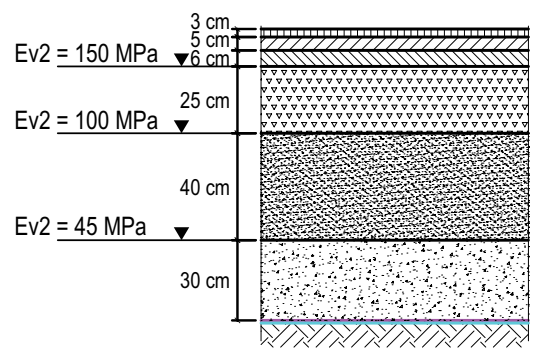

Asphalt concrete SMA $8 \mathrm{~S}$

Asphalt concrete AC 16 AS

Asphalt concrete AC 22 PS

Crushed asphalt concrete and crushed dolomite mix. 22/56

Protective frost resistant soil layer

Gravel and sand mix. 0/16

Geogrid from PP 60/60 kN/m (crosswise direction)

Nonwoven geotextile GRK3

Existing embankment

Note: national road No. $131(53.91-54.09$ km, $55.00-55.09$ km, and $56.74-56.94 \mathrm{~km})$; measurements in $\mathrm{cm}$.

Figure 2. Road structure No. 2

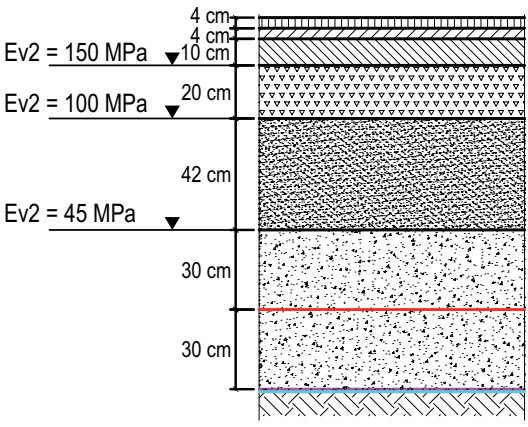

Asphalt concrete AC $11 \mathrm{VS}$

Asphalt concrete AC 16 AS

Asphalt concrete AC 22 PS

Crushed asphalt concrete and crushed dolomite mix. 22/56 Protective frost resistant soil layer

Gravel mix. 0/32

Geogrid from PP 60/60 kN/m (croswise direction)

Gravel mix. 0/32

Geogrid from PP 60/60 kN/m (crosswise direction)

Nonwoven geotextile GRK3

Existing embankment

Note: national road No. $131(45.300-45.380 \mathrm{~km}, 45.965-46.140 \mathrm{~km}$, $46.45-46.72 \mathrm{~km}, 46.865-46.950 \mathrm{~km}, 47.320-47.425 \mathrm{~km}$, and $49.220-49.295 \mathrm{~km}$ ); measurements in $\mathrm{cm}$.

Figure 3. Road structure No. 3

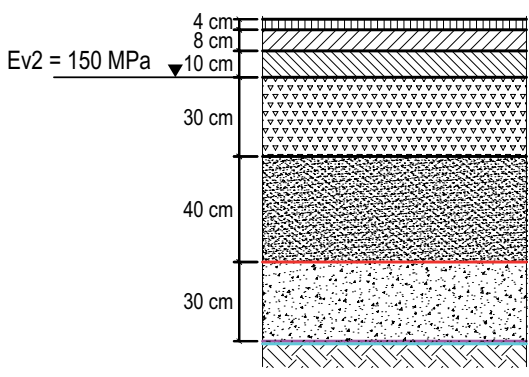

Asphalt concrete AC 11 VS

Asphalt concrete AC 16 AS

Asphalt concrete AC 32 PS

Crushed dolomite $16 / 56$ and $30 \%$ recycled asphalt mix. Protective frost resistant soil layer

Geogrid from PET 200/40 kN/m (Iongitudinal direction) Gravel mix. 0/32

Geogrid from PET 400/40 kN/m (crosswise direction)

Nonwoven geotextile GRK3

Existing embankment

Note: main road A6 (141.047-141.123 km); measurements in cm.

Figure 4. Road structure No. 4 


\section{General research conditions}

The road surface roughness is one of the main parameters that describe the driving comfort, and it is the indicator of the pavement condition. It is known that the asphalt pavement surface is also showing the crushed stone layer and frost-blanket course condition. If these layers are weak, the asphalt pavement becomes cracked or bumpy, and it has a negative influence on the IRI. The weak points are also the soft soils that are under the frost-blanket course, and the critical point is when the snow melts and the subgrade defrosts. At first, the remaining bearing capacity (Abu-Farsakh, Akond, \& Chen, 2016) of the soils has to be checked to determine if the geogrid reinforcement is working correctly. On this purpose, the tested section FWD measurements were made on the most unfavourable time for the bearing capacity. That was in the spring of 2018, just a few days after the soils defrosted.

This research aims to indicate how geogrid-reinforced subgrade sections compare to typical subgrade sections without any required strengthening ( $\geq 45 \mathrm{MPa}$ ), lime stabilised and pile strengthened subgrade on the pavement roughness and bearing capacity. Besides, to find out how solutions of geogrid-reinforced subgrade differ from each other by IRI and FWD measurements, especially having cold climate influence (Want, Hoff, \& Recker, 2016).

Before comparing the data, it is essential to know that geogrid has a lateral restraint effect (Sakleshpur Prezzi, Salgado, Siddiki, \& Choi, 2017) to the limited soil layer thickness. It is usually about $0.6 \mathrm{~m}$. The soil layer closest to the geogrid reinforcement is the primary layer for bearing capacity comparison. In a multilayer pavement system, the main characteristic of the base layer is its comparatively big bearing capacity. It widens the distribution of vertical loads and ultimately decreases the maximum vertical stresses acting at the base-subgrade interface (Zornberg, 2017) (Figure 4).

\section{Research methodology and used equipment}

Transport Competence Agency performed International Roughness Index measurements. The mobile road research laboratory RST-28 was used to take the IRI measurements. RST-28 laboratory is a mobile, multi-component pavement surface quality measuring unit, which uses 19 laser sensors, 2 accelerometers, 2 gyroscopes and 2 inclinometers that are mounted on the front measuring beam (laser frame). The measurements of the tested road sections were performed one year, four years and seven years after the road section reconstructions were 
finished. Measurements were taken in both driving lanes and for every driving track of the road measuring the IRI in the intervals at every $20 \mathrm{~m}$.

Dynamic deflection measurement equipment, Dynatest 8000 FWD applies a dynamic load (duration 25-30 ms) that simulates the loading of a moving wheel. Deflection measurements have an absolute $2 \% \pm 2 \mu \mathrm{m}$ and standard comparative $1 \% \pm 1 \mu \mathrm{m}$ precision. The load used for the tests is $50 \mathrm{kN}$. During the tests, the asphalt surface temperature was varying from $+13{ }^{\circ} \mathrm{C}$ to $+22{ }^{\circ} \mathrm{C}$. Comparing the deflection measurements, their values are reduced to the standard loading of $50 \mathrm{kN}$ and a standard temperature of $+20{ }^{\circ} \mathrm{C}$. These deflection measurement values are used to calculate the bearing capacity $E$ of the road structure layer.

Deflection measurements were carried out in both driving lanes, on the left driving track. Each road section having a different type of subgrade was tested by measuring three places in that distance, taking more than $25 \mathrm{~m}$ from the beginning and the end of the section. The air temperature was measured at the beginning of the deflection test. Falling Weight Deflectometer measurements of the tested road sections were performed eleven years for road structure No. 1, nine years for road structure No. 2, eight years for road structures No. 3 and No. 4 after the road section reconstructions were finished.

Statistical data analysis was performed using essential statistical parameters defining the research data: average and standard deviation. Average and standard deviation values were calculated for different types of road structures taking all the values available for tested sections grouping them to non-reinforced subgrade, geogridreinforced subgrade, lime stabilised and pile strengthened subgrade. One tested section includes all IRI values available in both lanes and all-wheel tracks and all FWD values available in both lanes on the left wheel track.

\section{Comparison of the pavement roughness and bearing capacity}

Test sections have a different type of subgrade. In total, there are four types of subgrade:

- the first one is when the subgrade has stable natural soils that need no strengthening (non-reinforced);

- the second has a geogrid-reinforced subgrade over a peaty silty soils layers;
Aurimas Šiukščius, Viktoras Vorobjovas, Audrius Vaitkus, Šarūnas Mikaliūnas, Atis Zarinš

Long Term Behaviour of an Asphalt Pavement Structure Constructed on a GeogridReinforced Subgrade Over Soft Soils 
- the third one has lime stabilised subgrade over natural or filled clayey soil;

- the fourth one has piled subgrade with geogrid-reinforced soil platform over piles in places where are very deep peat layers.

\subsection{Main road A6 $(66.20-68.76 \mathrm{~km})$}

Geogrid-reinforced section compared to adjacent sections shows that measured IRI value of seven years after construction is below $2 \mathrm{~m} / \mathrm{km}$ (required limit value for newly constructed asphalt pavement on main roads). It has better average IRI result than non-reinforced section (Figures 5-6). The adjacent sections are without additional strengthening. Section $67.45-67.64 \mathrm{~km}$ has a $0.4 \mathrm{~m}$ thickness of the frost-blanket course when others have the old road structure as a frost-blanket course. The road structure No. 1 has $30 / 30 \mathrm{kN} / \mathrm{m}$ geogrid reinforcement under crushed dolomite 0/45 layer and is the weakest structure from this research. The geological situation, as described above, is the worst in this research. However, this structure shows that even having a bearing capacity of crushed dolomite weaker by $18.18 \%$ (in this instance the geogrid has the most significant influence to the crushed dolomite layer E2) compared to a non-reinforced section the average value of IRI of seven years after construction is $9.29 \%$ better compared to non-reinforced section. Taking as a starting point the average value of IRI at the first-year, it has been seen that the average value of IRI of seven years after

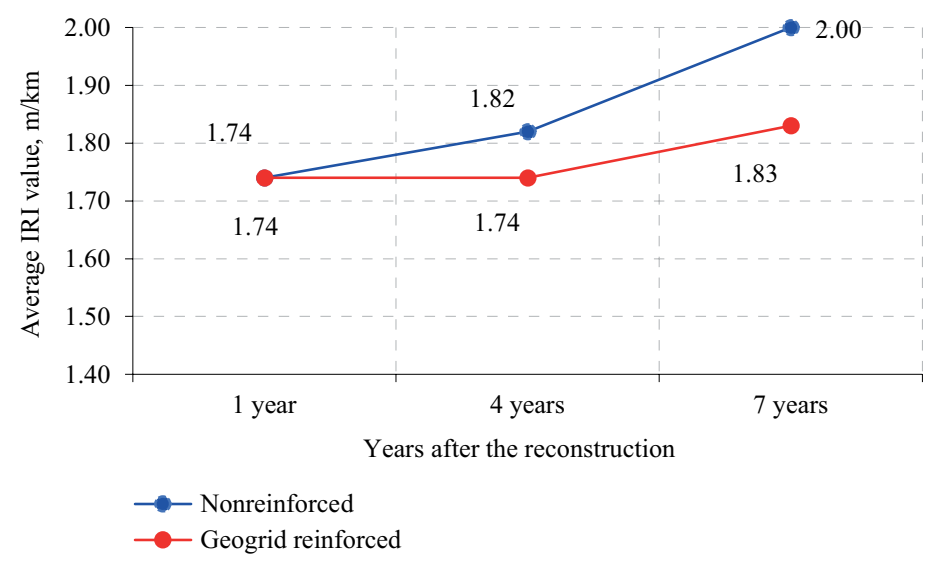

Figure 5. Average values of the International Roughness Index in the main road A6 (66.20-68.76 km) 
construction increased by $14.94 \%$ in non-reinforced section and increased only by $5.17 \%$ in geogrid-reinforced section. The variation of min/max values and standard deviation are much higher for a geogrid-reinforced section (Table 1).

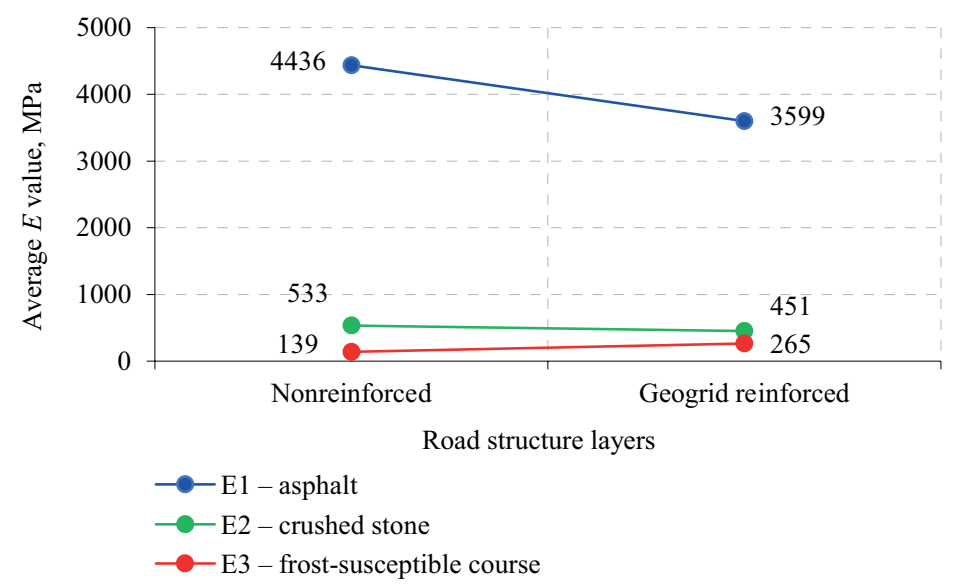

Figure 6. Average values of the bearing capacity in the main road A6 $(66.20-68.76 \mathrm{~km})$

Table 1. Statistical values by subgrade type of measurements
in the main road A6 (66.20-68.76 km)

Table 1. Statistical values by subgrade type of measurements
in the main road A6 (66.20-68.76 km)
Aurimas Šiukščius, Viktoras Vorobjovas, Audrius Vaitkus, Šarūnas Mikaliūnas, Atis Zarinš

Long Term Behaviour of an Asphalt Pavement Structure Constructed on a GeogridReinforced Subgrade Over Soft Soils

\begin{tabular}{|c|c|c|c|c|c|c|c|}
\hline \multirow{2}{*}{$\begin{array}{l}\text { Road } \\
\text { structure } \\
\text { type }\end{array}$} & & \multicolumn{3}{|c|}{$\begin{array}{c}\text { International Roughness } \\
\text { Index*, } \\
\mathrm{m} / \mathrm{km}\end{array}$} & \multicolumn{3}{|c|}{$\begin{array}{c}\text { Bearing capacity } \\
\text { for road structure layers, } \\
\mathrm{MPa}\end{array}$} \\
\hline & & 1 year & 4 years & 7 years & Asphalt & $\begin{array}{l}\text { Crushed } \\
\text { stone }\end{array}$ & Subgrade \\
\hline \multirow{3}{*}{ Non-reinforced } & minimum & 0.00 & 0.52 & 0.55 & 2709 & 318 & 62 \\
\hline & maximum & 6.82 & 5.01 & 6.75 & 6367 & 849 & 232 \\
\hline & $\begin{array}{l}\text { standard } \\
\text { deviation }\end{array}$ & 0.83 & 0.80 & 0.98 & 1217 & 190 & 60 \\
\hline \multirow{3}{*}{ Geogrid-reinforced - } & minimum & 0.96 & 1.02 & 0.93 & 3038 & 324 & 66 \\
\hline & maximum & 4.64 & 4.34 & 5.87 & 3969 & 757 & 530 \\
\hline & $\begin{array}{l}\text { standard } \\
\text { deviation }\end{array}$ & 0.73 & 0.61 & 1.04 & 386 & 164 & 210 \\
\hline
\end{tabular}

Note: * at years after reconstruction. 


\subsection{National road No. $131(52.45-57.12 \mathrm{~km})$}

Geogrid-reinforced section compared to adjacent sections shows that measured IRI value of seven years after construction is far below $2.5 \mathrm{~m} / \mathrm{km}$ (required limit value for newly constructed asphalt pavement on national roads). It has the best IRI average result (Figures 7-8). The geogridreinforced section has $0.4 \mathrm{~m}$ of the frost-blanket course and $0.3 \mathrm{~m}$ of the additional soil replacement when others have the old road structure as a frost-blanket course. The road structure No. 2 (53.91-54.09 km, 55.00$55.09 \mathrm{~km}$ and $56.74-56.94 \mathrm{~km}$ ) has one $60 / 60 \mathrm{kN} / \mathrm{m}$ geogrid reinforcement under additional granular soil $0 / 16$ layer. It is the third structure from this research by the total geogrid strength. At a depth from $1.1 \mathrm{~m}$ to $1.9 \mathrm{~m}$ under the geogrid reinforcement, there are up to $1.3 \mathrm{~m}$ of peat layers. Lime stabilised layers had $0.3 \mathrm{~m}$ thickness and had $3 \%$ of burnt lime.

Taking as a starting point the average value of IRI of seven years after construction for the geogrid-reinforced section it is $15.9 \%$ less than the average value of IRI for non-reinforced section and $21.59 \%$ less than the average value of IRI for by lime stabilised section. Taking as a starting point the average value of IRI of the first-year after construction it has been seen that the average value of IRI of seven years after construction increased only by $3.53 \%$ in geogrid-reinforced section, while this value increased by $10.87 \%$ in non-reinforced section and by $7.00 \%$ in lime stabilised section. The variation of $\mathrm{min} / \max$ values and the standard deviation are given in Table 2. Falling Weight Deflectometer results show that the best IRI performer for this section (geogrid-reinforced subgrade) has the most significant average values of bearing capacity for crushed stone and frost-blanket course (in this instance the geogrid has the most

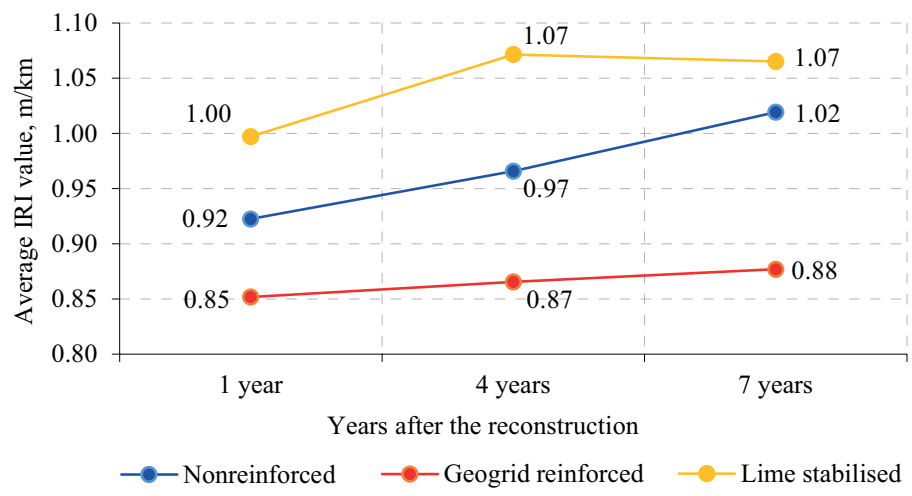

Figure 7. Average values of the International Roughness Index in the national road No. $131(52.45-57.12 \mathrm{~km})$ 
significant influence to the frost-blanket course E3). It also shows that the structure having less IRI values is showing more significant values of bearing capacity for crushed stone and frost-blanket course.

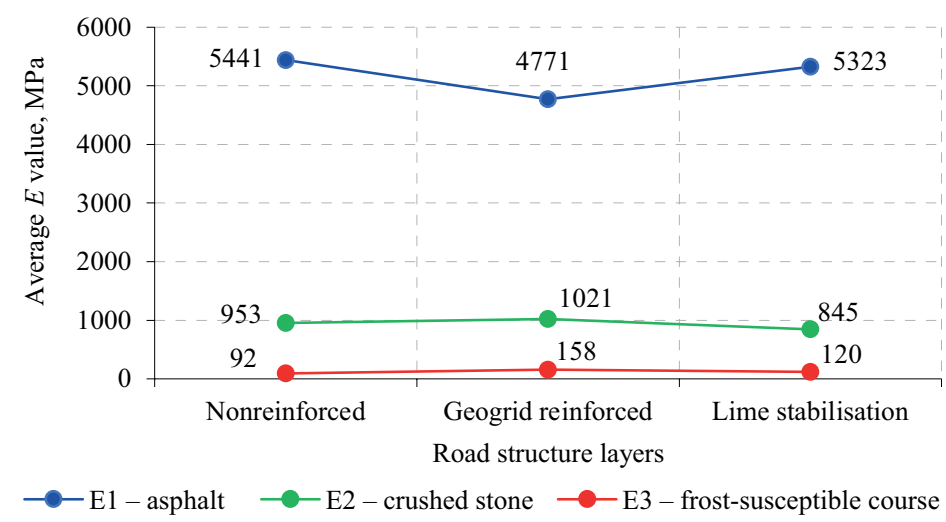

Aurimas Šiukščius, Viktoras Vorobjovas, Audrius Vaitkus, Šarūnas Mikaliūnas, Atis Zarinš

Long Term Behaviour of an Asphalt

Pavement Structure

Constructed on a Geogrid-

Reinforced Subgrade Over Soft Soils

Figure 8. Average values of bearing capacity in the national road No. $131(52.45-57.12 \mathrm{~km})$

Table 2. Statistical values by the type of subgrade structure of measurements in the national road No. $131(52.45-57.12 \mathrm{~km})$

\begin{tabular}{|c|c|c|c|c|c|c|c|}
\hline \multirow{2}{*}{\multicolumn{2}{|c|}{$\begin{array}{l}\text { Subgrade } \\
\text { structure } \\
\text { type }\end{array}$}} & \multicolumn{3}{|c|}{$\begin{array}{c}\text { International Roughness } \\
\text { Index*, } \\
\mathrm{m} / \mathrm{km}\end{array}$} & \multicolumn{3}{|c|}{$\begin{array}{c}\text { Bearing capacity } \\
\text { for road structure layers, } \\
\mathrm{MPa}\end{array}$} \\
\hline & & 1 year & 4 years & 7 years & Asphalt & $\begin{array}{l}\text { Crushed } \\
\text { stone }\end{array}$ & $\begin{array}{c}\text { Frost-blanket } \\
\text { course }\end{array}$ \\
\hline \multirow{3}{*}{$\begin{array}{l}\text { Non- } \\
\text { reinforced }\end{array}$} & minimum & 0.48 & 0.58 & 0.56 & 4349 & 682 & 73 \\
\hline & maximum & 1.72 & 2.31 & 2.64 & 6612 & 1228 & 124 \\
\hline & $\begin{array}{l}\text { standard } \\
\text { deviation }\end{array}$ & 0.27 & 0.32 & 0.37 & 845 & 186 & 18 \\
\hline \multirow{3}{*}{$\begin{array}{l}\text { Geogrid- } \\
\text { reinforced }\end{array}$} & minimum & 0.40 & 0.46 & 0.49 & 2653 & 292 & 65 \\
\hline & maximum & 1.59 & 1.59 & 1.35 & 8410 & 1589 & 256 \\
\hline & $\begin{array}{l}\text { standard } \\
\text { deviation }\end{array}$ & 0.22 & 0.20 & 0.20 & 1330 & 284 & 45 \\
\hline \multirow{3}{*}{$\begin{array}{l}\text { Lime } \\
\text { stabilised }\end{array}$} & minimum & 0.37 & 0.41 & 0.35 & 3250 & 687 & 98 \\
\hline & maximum & 7.50 & 6.79 & 8.23 & 6822 & 1414 & 242 \\
\hline & $\begin{array}{l}\text { standard } \\
\text { deviation }\end{array}$ & 0.66 & 0.69 & 0.69 & 910 & 212 & 45 \\
\hline
\end{tabular}

Note: *at years after reconstruction. 


\subsection{National road No. $131(44.80-50.80 \mathrm{~km})$}

Geogrid-reinforced section compared to adjacent sections shows that seven years after construction measured IRI value is also below $2.5 \mathrm{~m} / \mathrm{km}$ (required limit value for newly constructed asphalt pavement on national roads). However, it has significant IRI average result only compared to piled embankment section (Figures 9-10) while from lime stabilised and non-reinforced sections were received more significant results. All four different subgrade types were split into two groups showing similar geological situation:

A) non-reinforced and lime stabilised subgrades;

B) geogrid-reinforced and piled subgrades.

Group A has no peaty or silty soft soils under the structure while group B is used over soft peaty and silty soils having much more complicated conditions. Road structure layer thicknesses (asphalt concrete, crushed stone and frost-blanket course) are the same for all sections. The road structure No. $3(45.965-46.140 \mathrm{~km} ; 46.45-46.72 \mathrm{~km}$; $46.865-46.950 \mathrm{~km} ; 47.320-47.425 \mathrm{~km}$, and $49.220-49.295 \mathrm{~km}$ ) has two $60 / 60 \mathrm{kN} / \mathrm{m}$ geogrid reinforcement layers under additional granular soil $0 / 32$ layer. It is the second structure from this research by the total geogrid strength. At a depth from $0.6 \mathrm{~m}$ to $1.7 \mathrm{~m}$ under the geogrid reinforcement there is up to $1.3 \mathrm{~m}$ peat layers. Lime stabilised layers had $0.3 \mathrm{~m}$ thickness and had $3 \%$ of burnt lime. Piled embankment sections have an additional $0.3 \mathrm{~m} \mathrm{0} / 32$ gravel layer between the road structure and pile caps.

Taking the average value of IRI seven years after construction for the geogrid-reinforced section as a starting point, it is $4.31 \%$ less than

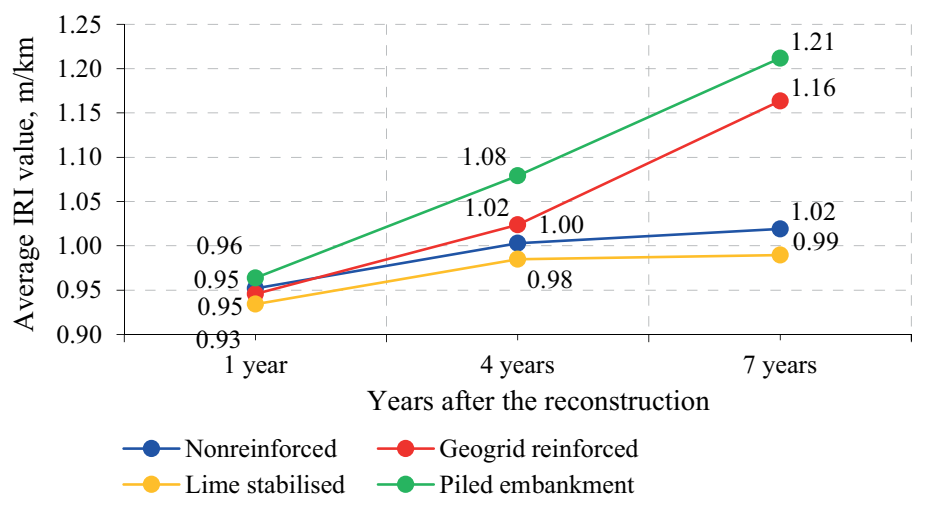

Figure 9. Average values of the International Roughness Index in the national road No. 131 (44.80-50.80 km) 


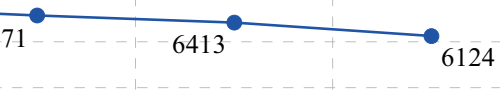

Nonreinforced

\section{Atis Zariňs}

Long Term Behaviour of an Asphalt

Pavement Structure

Constructed

on a Geogrid-

Reinforced Subgrade

Over Soft Soils

Table 3. Statistical values by the type of subgrade structure of measurements in the national road No. $131(44.80-50.80 \mathrm{~km})$

Figure 10. Average values of bearing capacity in the national road No. $131(44.80-50.80 \mathrm{~km})$

$$
\begin{array}{lcc}
\text { Geogrid } & \text { Piled } & \text { Lime stabilised } \\
\text { reinforced } & \text { embankment }
\end{array}
$$

$\longrightarrow$ E1 - asphalt $\longrightarrow$ E2 - crushed stone $\longrightarrow$ E3 - frost-susceptible course

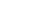


average value of IRI for piled subgrade section. However, $12.07 \%$ more than average value of IRI for lime stabilised section and $14.66 \%$ more for lime stabilised section. Taking the first-year average value of IRI as a starting point, it has been seen that seven years after construction geogrid-reinforced section average value of IRI increased by $22.11 \%$, piled subgrade section increased by $26.04 \%$, while non-reinforced section increased by $7.37 \%$ and lime stabilised by only $6.45 \%$. The variation of $\mathrm{min} / \mathrm{max}$ values and the standard deviation are given in Table 3. Falling Weight Deflectometer results show that the highest average values if the bearing capacity for crushed stone and frostblanket course are for the geogrid-reinforced and piled subgrade sections (B group). Burnt lime stabilised sections has the smallest average values of the bearing capacity. Unfortunately, it is impossible to compare it to the non-reinforced section because it has only one measurement point (Figure 10).

\subsection{Main road A6 $(137.35-142.00 \mathrm{~km})$}

This geogrid-reinforced section is in the least complicated geological conditions from all geogrid-reinforced sections in this research. From the bottom geogrid layer to the $0.4 \mathrm{~m}$ thickness peat layer, there are even $1.73 \mathrm{~m}$ filled soil layer. The road structure has the strongest geogrids in this research. Compared to adjacent sections geogrid-reinforced section shows that seven years after construction measured IRI value is also below $2 \mathrm{~m} / \mathrm{km}$ (required limit value for newly constructed asphalt pavement on main roads). However, it has the worst IRI average result compared to other subgrade structure type sections (Figures 11-12). All four different subgrade types were split into two groups showing similar geological situation:

A) non-reinforced and lime stabilised subgrades;

B) geogrid-reinforced and piled subgrades.

Group A has no peaty or silty soft soils under the structure. Group $B$ is used over soft peaty and silty soils having much more complicated conditions. Road structure layer thicknesses (asphalt concrete, crushed stone and frost-blanket course) are the same for all sections except for some parts of non-reinforced sections where there is existing road subgrade as a frost-blanket course The road structure No. 4 $(141.05-141.12 \mathrm{~km})$ has two geogrids $400 / 40 \mathrm{kN} / \mathrm{m}$ and $200 / 40 \mathrm{kN} / \mathrm{m}$ reinforcement under additional $0.3 \mathrm{~m}$ granular soil $0 / 32$ layer. Lime stabilised layers had $0.3 \mathrm{~m}$ thickness and had $3 \%$ of burnt lime. Piled embankment sections have an additional $0.3 \mathrm{~m} 0 / 32$ gravel layer between the road structure and pile caps. 
The average value of IRI seven years after construction for the geogrid-reinforced section is $1.61 \mathrm{~m} / \mathrm{km}$. It is $10.56 \%$ more than average value of IRI for non-reinforced section, $14.91 \%$ more than a lime stabilised section and $22.36 \%$ more than average value of IRI for piled subgrade section. Taking the first-year average value of IRI as a starting point, it has been seen that seven years after construction geogrid-reinforced section average value of IRI increased by $15.83 \%$, piled subgrade section increased by $7.76 \%$, non-reinforced section increased by $6.67 \%$ while lime stabilised by $28.04 \%$. The variation of $\mathrm{min} / \mathrm{max}$ values and the standard deviation are given in Table 4.

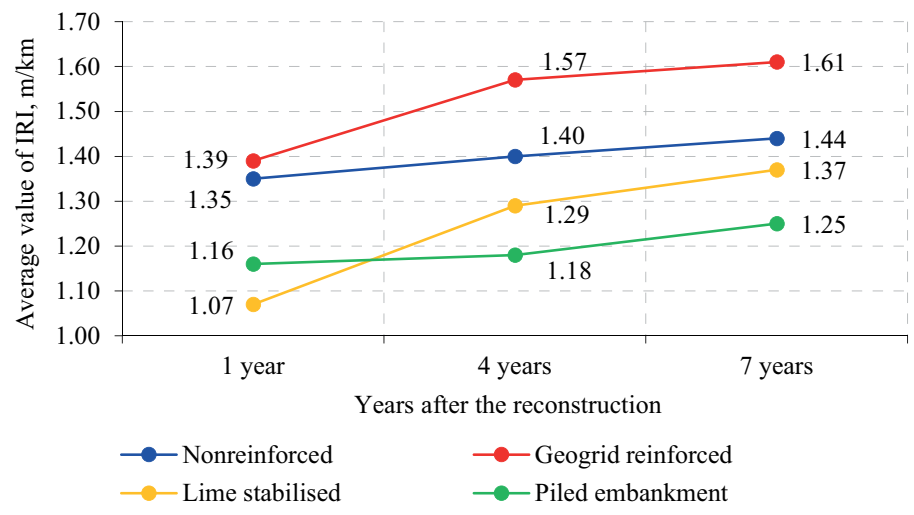

Figure 11. Average values of the International Roughness Index in the main road A6 $(137.35-142.00 \mathrm{~km})$

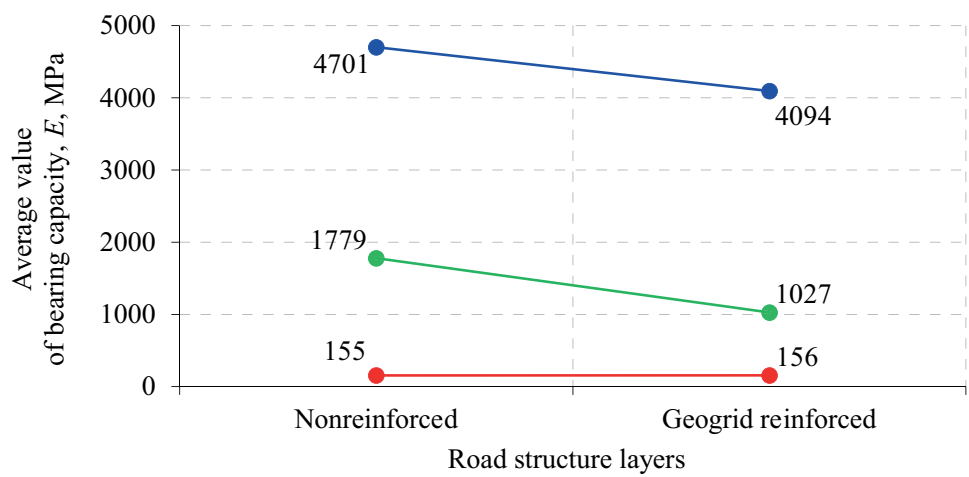

$\multimap$ E1 - asphalt $\longrightarrow$ E2 - crushed stone $\longrightarrow$ E3 frost-susceptible course

Figure 12. Average values of bearing capacity in the main road A6 (137.35-142.00 km)
Aurimas Šiukščius, Viktoras Vorobjovas, Audrius Vaitkus, Šarūnas Mikaliūnas, Atis Zarin̄s

Long Term Behaviour of an Asphalt Pavement Structure Constructed on a GeogridReinforced Subgrade Over Soft Soils 
Table 4. Statistical values by subgrade structure type of measurements in the main road $A 6(137.35-142.00 \mathrm{~km})$

\begin{tabular}{|c|c|c|c|c|c|c|c|}
\hline \multirow{2}{*}{\multicolumn{2}{|c|}{$\begin{array}{c}\text { Subgrade structure } \\
\text { type }\end{array}$}} & \multicolumn{3}{|c|}{$\begin{array}{l}\text { International Roughness } \\
\text { Index, } \\
\mathrm{m} / \mathrm{km}\end{array}$} & \multicolumn{3}{|c|}{$\begin{array}{c}\text { Bearing capacity } \\
\text { for road structure layers, } \\
\mathrm{MPa}\end{array}$} \\
\hline & & 1 year & 4 years & 7 years & Asphalt & $\begin{array}{l}\text { Crushed } \\
\text { stone }\end{array}$ & $\begin{array}{c}\text { Frost-blanket } \\
\text { course }\end{array}$ \\
\hline \multirow{3}{*}{$\begin{array}{l}\text { Non- } \\
\text { reinforced }\end{array}$} & minimum & 0.50 & 0.46 & 0.54 & 3541 & 1190 & 110 \\
\hline & maximum & 5.75 & 3.83 & 7.08 & 6701 & 2416 & 234 \\
\hline & $\begin{array}{l}\text { standard } \\
\text { deviation }\end{array}$ & 0.66 & 0.44 & 0.73 & 1099 & 363 & 39 \\
\hline \multirow{3}{*}{$\begin{array}{l}\text { Geogrid- } \\
\text { reinforced }\end{array}$} & minimum & 1.03 & 0.98 & 0.95 & 2706 & 780 & 75 \\
\hline & maximum & 1.64 & 2.70 & 2.65 & 6287 & 1225 & 235 \\
\hline & $\begin{array}{l}\text { standard } \\
\text { deviation }\end{array}$ & 0.18 & 0.43 & 0.45 & 1264 & 156 & 69 \\
\hline \multirow{3}{*}{$\begin{array}{l}\text { Lime } \\
\text { stabilized }\end{array}$} & minimum & 0.52 & 0.73 & 0.67 & - & - & - \\
\hline & maximum & 1.82 & 3.30 & 2.95 & - & - & - \\
\hline & $\begin{array}{l}\text { standard } \\
\text { deviation }\end{array}$ & 0.26 & 0.52 & 0.49 & - & - & - \\
\hline \multirow{3}{*}{$\begin{array}{l}\text { Piled } \\
\text { subgrade }\end{array}$} & minimum & 0.56 & 0.44 & 0.59 & - & - & - \\
\hline & maximum & 2.64 & 2.49 & 2.68 & - & - & - \\
\hline & $\begin{array}{l}\text { standard } \\
\text { deviation }\end{array}$ & 0.35 & 0.33 & 0.37 & - & - & - \\
\hline
\end{tabular}

Note: * at years after reconstruction.

Falling Weight Deflectometer results show that the average value of the bearing capacity in the geogrid-reinforced subgrade section for the crushed stone layer is less by $73.22 \%$. However, for the frost-blanket course, it is bigger by $0.64 \%$ (in this instance, the geogrid has the most significant influence on the frost-blanket course bearing capacity E3). Unfortunately, there is no data for bearing capacity for lime stabilised and piled subgrade sections.

\section{Geogrid evaluation}

Statistical analysis is used for all types of structures to see if pavement deterioration tendency for geogrid-reinforced subgrade section is similar to non-reinforced subgrade section pavement 
deterioration, which is the control section. Statistical analysis of the IRI and bearing capacity values was performed to obtain the coefficient of variation (CV) values to be able to compare the results of the test. The smaller the coefficient of variation, the more precise is the result of the test (IRI and FWD for each type of structure); for IRI, it means that the pavement is smoother, and for FWD, it means that the pavement is more homogeneous. While the aim is to compare asphalt pavement surface roughness and bearing capacity for the geogrid-reinforced subgrade with the non-reinforced subgrade sections, the statistical analysis covers only these two types of subgrade. Table 5 shows that road structure No. 1 has quite a similar CV for both subgrade types, except the bearing capacity for the frost-blanket course because the geogrid is installed under a crushed stone layer. The coefficient of variation for IRI shows an excellent precision result for road structures No. 2 and No. 4. In general, comparing the precision of the results, there is no significant difference between both subgrade types at each road structure type.

As for the geogrid, the main parameters for a soil stabilisation/ reinforcement is to have a stiff aperture, maintain high tensile strength at low elongations and to have adequate long term design strength (Cuelho, Perkins, \& Morris, 2014). In addition, the optimum nominal aperture size has to be about four times of medium grain size of the fill material (Mehrjardi \& Khazaei, 2017). All geogrid-reinforced sections had geogrids that were made from PP or PET bars welded injunctions (laid geogrids), which means - stiff geogrids. It is feasible to adopt the

Table 5. Values of the variation coefficient in the tested road sections

\begin{tabular}{|c|c|c|c|c|}
\hline \multirow{4}{*}{\multicolumn{2}{|c|}{$\begin{array}{c}\text { Road } \\
\text { structure }\end{array}$}} & \multicolumn{3}{|c|}{ Road structure parameter } \\
\hline & & \multirow{3}{*}{$\begin{array}{l}\text { Asphalt layer } \\
\text { roughness } \\
\text { IRI, m/km }\end{array}$} & Crushed stone & Frost-blanket course \\
\hline & & & \multicolumn{2}{|c|}{ Bearing capacity } \\
\hline & & & $\mathrm{E} 2, \mathrm{MPa}$ & E3, MPa \\
\hline \multirow{2}{*}{ No. 1} & A & 0.568 & 0.364 & 0.792 \\
\hline & B & 0.490 & 0.356 & 0.432 \\
\hline \multirow{2}{*}{ No. 2} & A & 0.227 & 0.208 & 0.285 \\
\hline & B & 0.363 & 0.195 & 0.196 \\
\hline \multirow{2}{*}{ No. 3} & A & 0.457 & 0.228 & 0.357 \\
\hline & B & 0.294 & - & - \\
\hline \multirow{2}{*}{ No. 4} & A & 0.280 & 0.152 & 0.442 \\
\hline & $\mathrm{B}$ & 0.507 & 0.204 & 0.252 \\
\hline
\end{tabular}

Note: A - geogrid-reinforced subgrade; B - non-reinforced subgrade.
Aurimas Šiukščius, Viktoras Vorobjovas, Audrius Vaitkus, Šarūnas Mikaliūnas, Atis Zarinš

Long Term Behaviour of an Asphalt Pavement Structure

Constructed on a GeogridReinforced Subgrade Over Soft Soils 


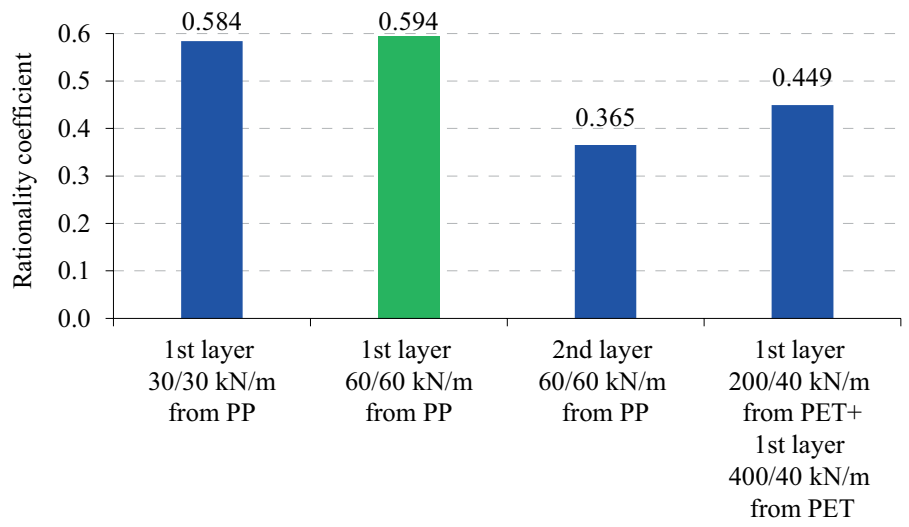

Figure 13. Rationality coefficients for geogrid structure types

total tensile strength at $1 \%$ elongation and long-term design strength values as the main geogrid parameters for four types of geogridreinforced constructions having these parameters.

To be able to choose the best option for the subgrade reinforcement with geogrids a Simple Additive Weighting (SAW) method was used evaluating the criteria of IRI, geogrid tensile strength at $1 \%$ elongation, geogrid long term design strength and geogrid price. Every criterion has its importance coefficient used for the decision matrix and calculation. The result of the calculation is rationality coefficient. The higher the rationality coefficient, the more rational is the reinforcement type. The best option for the geogrid reinforcement in this research is one geogrid layer $60 / 60 \mathrm{kN} / \mathrm{m}$ from PP (Figure 13).

It is stated that using two layers of geogrid reinforcement trying to improve the long-term performance of the road structure over the peaty soils, which lay more in-depth in the subgrade, is irrational.

\section{Conclusions and recommendations}

1. This research proves that geogrid reinforcement is sufficient to be used over a well-decomposed peat and silt layers, which lays deeper in the subgrade to maintain the International Roughness Index at a similar level compared to strong non-reinforced subgrades.

2. Average International Roughness Index values for geogrid-reinforced subgrade sections vary from $0.88 \mathrm{~m} / \mathrm{km}$ to $1.83 \mathrm{~m} / \mathrm{km}$ when for non-reinforced sections it vary from $1.02 \mathrm{~m} / \mathrm{km}$ to $2.00 \mathrm{~m} / \mathrm{km}$. This statement leads to a conclusion that even having much worse geological situation, geogrid-reinforced sections overall performs 
slightly better than non-reinforced sections. This conclusion means that geogrids are reducing fatigue of the structure by absorbing cyclic loading forces. This geogrid feature is compensating for poor subgrade properties to maintain a designed lifetime of road structure.

3. Calculated variation coefficients for International Roughness Index shows that the stability and precision of test results are better for geogrid-reinforced subgrade sections at road structures No. 2 and No. 4, but worse at road structures No. 1 and No. 3 compared to nonreinforced subgrade sections. As for bearing capacity of crushed stone and frost-blanket course, geogrid-reinforced subgrade sections at road structures No. 1 and No. 2 are slightly worse and for structure No. 4 slightly better for crushed stone layer compared to nonreinforced subgrade sections. Overall, geogrid-reinforced subgrade sections over peat and slit soils show International Roughness Index and bearing capacity results in a similar level as for non-reinforced subgrade sections over firm soils.

4. The research covers only a stiff laid geogrids that were installed in the subgrade, and it proves that geogrid stiffness, high tensile strength at low elongations and adequate long-term design strength are the key parameters to describe the geogrid performance.

5. The purpose of using geogrid reinforcement over up to $3 \mathrm{~m}$ thickness well-decomposed peat layers, was to avoid the excavation of peat and soil replacement piled subgrade installation due to the money savings for investor and significantly shorter installation time (depending on the area, saves up to few months) for the contractor. The research shows that the solution is working as it was expected theoretically.

\section{REFERENCES}

Abu-Farsakh, M. Y., Akond, I., \& Chen, Q. (2016). Evaluating the performance of geosynthetic-reinforced unpaved roads using plate load tests. International Journal of Pavement Engineering, 17(10), 901-912. https://doi.org/10.1080/10298436.2015.1031131

Cuelho, E. \& Perkins, S. (2016). Mechanisms of Reinforced Benefit from Geosynthetics Used as Subgrade Stabilization, $6^{\text {th }}$ European Geosynthetics Congress "EuroGeo6": 450-461.

Cuelho, E., Perkins, S., \& Morris, Z. (2014). Relative operational performance of geosynthetics used as subgrade stabilization:[project summary] (No. 7712-251/ TPF-5 (251)). Montana. Dept. of Transportation. Research Programs.

IT APM 10 Automobilių keliu asfalto dangu priežiūrai skirtų medžiagų ir medžiagu mišiniu panaudojimo ir jų sluoksnių įrengimo taisyklès (in Lithuanian)
Aurimas Šiukščius, Viktoras Vorobjovas, Audrius Vaitkus, Šarūnas Mikaliūnas, Atis Zarinš

Long Term Behaviour of an Asphalt

Pavement Structure

Constructed on a Geogrid-

Reinforced Subgrade Over Soft Soils 
IT ŽS 17 Automobiliu keliu žemès darbu atlikimo ir žemés sankasos ịrengimo taisyklès (in Lithuanian)

KTR 1.01:2008 Automobilių keliai (in Lithuanian)

Mehrjardi, G. T., \& Khazaei, M. (2017). Scale effect on the behaviour of geogrid-reinforced soil under repeated loads. Geotextiles and Geomembranes, 45(6), 603-615. https://doi.org/10.1016/j.geotexmem.2017.08.002

Meyer, N., \& Elias, J. M. (1999). Design methods for roads reinforced with multifunctional geogrid composites for subbase stabilization. Kunststoffe in de Geotechnik.

MN GEOSINT ŽD 13 Geosintetikos naudojimo žemès darbams keliuose metodiniai nurodymai (in Lithuanian)

Sakleshpur, V. A., Prezzi, M., Salgado, R., Siddiki, N. Z., \& Choi, Y. S. (2019). Large-scale direct shear testing of geogrid-reinforced aggregate base over weak subgrade. International Journal of Pavement Engineering, 20(6), 649-658. https://doi.org/10.1080/10298436.2017.1321419

Šiukščius, A., Vorobjovas, V., \& Vaitkus, A. (2017). Geogrid reinforced subgrade influence to ensure paved road durability. In Environmental Engineering. Proceedings of the International Conference on Environmental Engineering. ICEE (Vol. 10, pp. 1-7). Vilnius Gediminas Technical University, Department of Construction Economics \& Property. https://doi.org/10.3846/enviro.2017.148

Šiukščius, A., Vorobjovas, V., \& Vaitkus, A. (2018). Geogrid reinforced road subgrade influence to the pavement evenness, IOP Conference Series: Materials Science and Engineering "Resilient and Safe Road Infrastructure": 356.

Vaitkus, A., Čygas, D., Motiejūnas, A., Pakalnis, A., \& Miškinis, D. (2016). Improvement of Road Pavement Maintenance Models and Technologies. Baltic Journal of Road \& Bridge Engineering, 11(3). https://doi.org/10.3846/bjrbe.2016.28

Vaitkus, A., Šiukščius, A., \& Ramūnas, V. (2014). Regulations for use of geosynthetics for road embankments and subgrades. The Baltic Journal of Road and Bridge Engineering, 9(2), 88-88.

https://doi.org/10.3846/bjrbe.2014.11

Valero, S., Sprague, J., \& Wrigley, N. (2014). Full scale trafficking of geogrid reinforced sections under realistic service conditions, $10^{\text {th }}$ International Conference on Geosynthetics "10ICG": 212.

Vollmert, L., Emerslen, A., \& Retzlaff, J. (2014). Cyclic stressing of geogrids in the working-load range of bound road constructions, $10^{\text {th }}$ International Conference on Geosynthetics "10ICG": 157.

Wallbaum, H., Busser, S., Itten, R., \& Frischknecht, R. (2014). Environmental benefits by using construction methods with geosynthetics, $10^{\text {th }}$ International Conference on Geosynthetics "10ICG": 224.

Want, A., Hoff, I., \& Recker, C. (2016). Geosynthetic reinforcement for road pavements in cold climate, $6^{\text {th }}$ European Geosynthetics Congress "EuroGeo6": 915-926.

Zornberg, J. G. (2017). Functions and applications of geosynthetics in roadways. Procedia engineering, 189, 298-306.

https://doi.org/10.1016/j.proeng.2017.05.048 